症例

$$
\begin{aligned}
& \text { 術前診断が可能であった左傍十二指腸へルニアの } 1 \text { 例 } \\
& \text { 白石共立病院外科, 山口大学器官制御医科学 (第 } 1 \text { 外科)* } \\
& \text { 大楽耕司岸川正彦榎 忠 彦* } \\
& \text { 野 島 真 治* 濱 野 公 一* }
\end{aligned}
$$

今回われわれは術前に診断しえた左傍十二指腸へルニア症例を経験した。症例は27歳, 男性. 平成11年 4 月頃より上腹部痛を認めたため近医を受診した. 腹部エコーや上部消 化管内視鏡検查を施行されたが，原因は不明であったため経過観察された，しかしその 後も腹痛の改善がみられないため, 平成 12 年 5 月に当院受診となった. 受診時臍上部に 疼痛を認めたが, 筋性防御はなかった。上部消化管造影検查や腹部 CT 検査で胃背側, 膵前方に小腸を羿め左傍十二指腸へルニアと診断した。このため開腹術下にへルニア門 を閉鎖した．傍十二指腸ヘルニアは急性腹症で発症し街中に確診されることが多いが， 本症例のように上部消化管造影検査や腹部 CT 検査での診断も可能である.そのために は本疾患の存在を念頭におくことが必要で,これにより緊急手術を回避することが可能 であると考えられる。

索引用語: 左傍十二指腸ヘルニア, 画像影断, 内ヘルニア

\section{緒 言}

傍十二指腸へルニアは比較的稀な疾患で急性腹症と して開腹され，術中に診断されたり腸管壊死により腸 切除を余儀なくされることが多い.今回われわれは術 前に上部消化管造影検查と腹部 CT 検查で診断しえた 左傍十二指腸へルニア症例を経験したので，文献的考 察を加えて報告する。

$$
\text { 症例 }
$$

症例：27歳, 男性.

主訴: 上腹部痛。

既往歴： 2 歳時, 鼠徍ヘルニア.

家族歴：特記すべき事なし。

現病歴：平成11年 4 月頃より上腹部痛を主訴に近医 を受診した，同院で上部消化管内視鏡検查や腹部エコ 一検查を施行されたが原因は不明であった。このため 経過観祭されたが，腹痛の消失がみられなかったため 平成12年 5 月 7 日に当院受診となった.

入院時現症：身長 $170 \mathrm{~cm}$, 体重 $73 \mathrm{~kg}$ で血圧・脈拍等 に異常はなかった，腹部は臍上部に疼痛を認めたが，
平坦で軟らかく腫瘤など触知しなかった。

入院時検查所見：T-Bil が軽度上昇していたが，他 には末梢血・血液生化学検査とも異常はなかった（表

\begin{tabular}{|c|c|c|c|}
\hline \multicolumn{2}{|l|}{ 血算 } & \multicolumn{2}{|c|}{ 血液生化学 } \\
\hline WBC & $8.700 / \mu 1$ & $\mathrm{TP}$ & $7.9 \mathrm{~g} / \mathrm{dl}$ \\
\hline $\mathrm{RBC}$ & $519 \times 10^{4} / \mu 1$ & Alb & $4.7 \mathrm{~g} / \mathrm{dl}$ \\
\hline $\mathrm{Hb}$ & $16.6 \mathrm{~g} / \mathrm{dl}$ & Glu & $88 \mathrm{mg} / \mathrm{dl}$ \\
\hline $\mathrm{Ht}$ & $45.9 \%$ & $\mathrm{~TB}$ & $1.3 \mathrm{mg} / \mathrm{dl}$ \\
\hline Plt & $22.6 \times 10^{4} / \mu 1$ & GOT & $18 \mathrm{U} / 1$ \\
\hline \multicolumn{2}{|c|}{ 白血球行画 } & GPT & $22 \mathrm{U} / \mathrm{I}$ \\
\hline Stab & $0 \%$ & $\gamma$ GTP & $19 \mathrm{U} / 1$ \\
\hline Seg & $55 \%$ & ALP & $135 \mathrm{U} / 1$ \\
\hline Eosino & $4 \%$ & $\mathrm{LDH}$ & $139 \mathrm{U} / 1$ \\
\hline Baso & $0 \%$ & Ch-E & $302 \Delta \mathrm{PH}$ \\
\hline Lympho & $36 \%$ & $\mathrm{~T}$-cho & $187 \mathrm{mg} / \mathrm{dl}$ \\
\hline \multirow[t]{6}{*}{ Mono } & $5 \%$ & BUN & $10.4 \mathrm{mg} / \mathrm{dl}$ \\
\hline & & Crea & $0.8 \mathrm{mg} / \mathrm{dl}$ \\
\hline & & CRP & $0.03 \mathrm{mg} / \mathrm{dl}$ \\
\hline & & $\mathrm{Na}$ & $142.2 \mathrm{mmol} / 1$ \\
\hline & & $\mathrm{K}$ & $3.65 \mathrm{mmol} / 1$ \\
\hline & & $\mathrm{Cl}$ & $107 \mathrm{mmol} / \mathrm{l}$ \\
\hline
\end{tabular}
1 ).

上部消化管造影検査: Treitz 勒帯より肛門側の小 腸が通常の走行と異なり, 胃体部背側を走行していた

\section{表 1 入院時検查成績}




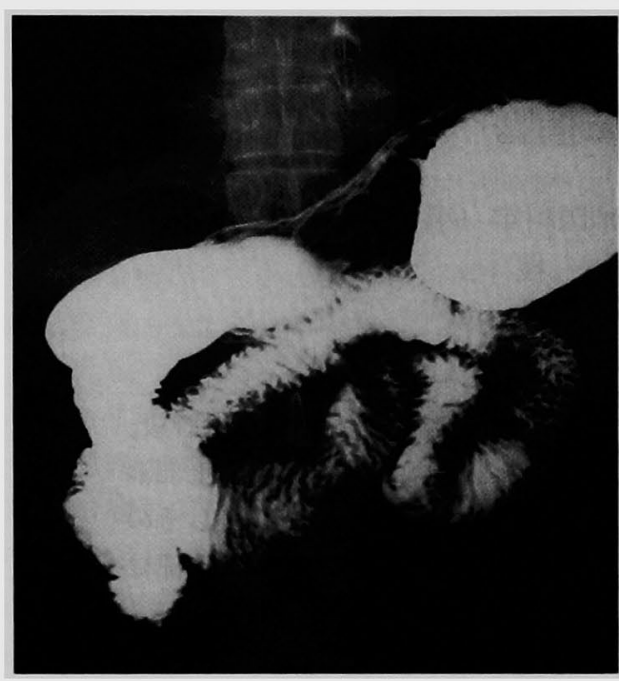

図 1 上部消化管造影検査：Treitz 䩓带より肛 門側の小腸が胃体部背側を走行していた。

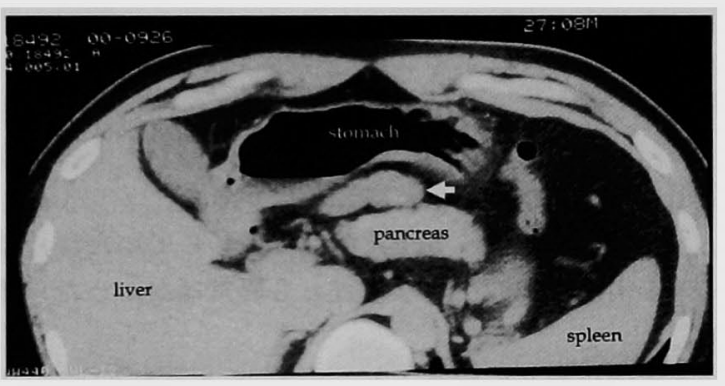

図 2 腹部 CT 検査 : 胃背側, 脺腹側に小腸係蹄を認め た（知印．

\section{(図 1 ).}

腹部エコ一検査：腸管の拡張や fluid の貯留は認め なかったまた，肝・胆道系にも異常は認めなかった。

腹部 CT 検査：胃背側, 脺腹側に小腸係蹄を認めた。 しかし，腸管の㹡張は明らかではなかった（図 2 ）。

以上より,今回の腹痛の原因として左傍十二指腸へ ルニアを考え, イレウス症状はなかったが患者の精神 的苦痛も強く, 家族の希望もあり平成 12 年 5 月 30 日に 手術を施行した。

手術所見 : 上腹部正中切開で開腹した. 開腹時, 腹 水の貯留は認めなかった. 小腸は全体に壊死や浮腫な どの所見はみられなかった. Treitz 靭帯左側の結腸間 膜に長径約 $8 \mathrm{~cm}$ 大の裂孔を認め，これをへルニア門 として小腸が陥入していた，陥入した小腸は飲頓の可 能性が考えられた。これより, 陥入した小腸を腹腔内

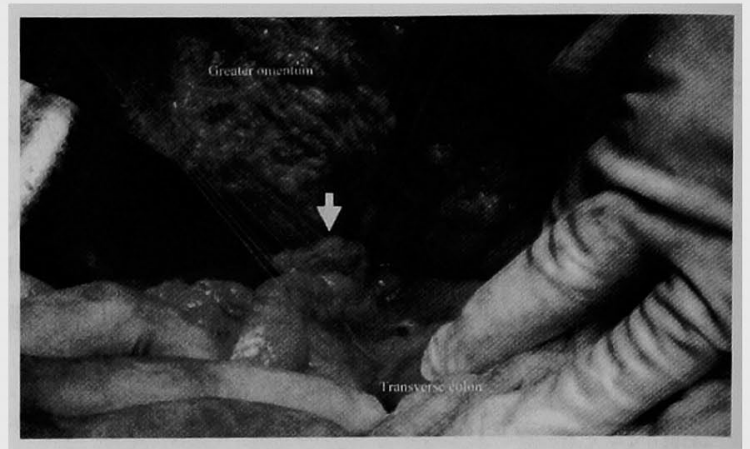

図 3 手術所見: Treitz 靶帯左側の結腸間膜にへルニア 門を認め, 小腸が陥入していた。 小腸を腹腔内に還納し ヘルニア門を閉鎖した（知印）.

に還納しへルニア門を閉鎖した（図 3 ).

術後経過：特に問題なく経過し，第 8 病日に退院と なった。

\section{考察}

傍十二指腸へルニアは十二指腸空腸㸗ヘルニアとも いわれ，十二指腸近傍にある腹腔裔へ腸管が陥入する 内へルニアの一種である"1. 頻度としては欧米の報告 によると, 内へルニアの約 $50 \%$ を占めている2!. 本邦て

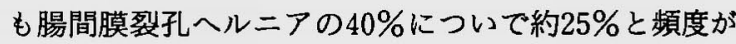
高い疾患ではあるが，内へルニア自体の頻度が少ない ため比較的稀な疾患である ${ }^{3 / 4)}$. 本症は胎生学的に発生 過程の違いから左右の 2 型に分類されている。いずれ も胎生期の中腸の回転異常によるとされている35). 右 ヘルニアは小腸の回転が途中で止まった結果生じ,一 方左ヘルニアは回転は正常に起こるが小腸が下腸間膜 静脈の後方に入り込んだ結果生じるとされている.つ まり右側は辺緑に上腸間膜動静脈がありヘルニア門は 左を向きへルニア业は右に存在し，左側は辺縁に下腸 間膜動静脈がありへルニア門は右を向きヘルニア蓄は

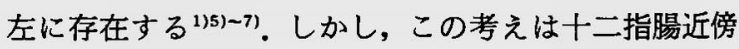
の 6 つの窝のうち, ヘルニアの発生頻度が高い腸間膜 側壁暴と傍十二指腸裔の 2 つを強調したものであり, 実際には左右診断に矛盾を生じることがあるとの報告 もある ${ }^{6}$. そして左右の判定には 6 つの窝を理解する とともに，臨床的に術中損傷を予防するため左右別よ りも上・下腸間膜動静脈へルニアの 2 つに分類してお くほうがよいと記されている6). 頻度としては左側が $75 \%$, 右側が $25 \%$ と左側が 3 倍多いとされている22. 本 症例も左側であった。 また本邦の統計では, 本疾患は 男性 $75.5 \%$ 女性 $24.5 \%$ と男性に多くみられ，年齢は 
生後 3 日より75歳までばらつきなく認められてい $3^{778)}$. 症状としては腹部膨満感・間欠的腹痛・嶇吐・ 腹部腫痹などが認められるが，主としてイレウス症状 が前面にでる8) -10)。 また，本症例のように反復する腹 痛を長期にわたり認める症例が存在する.菊野ら ${ }^{10}$ は, 急性・慢性のイレウス症状と腹部の限局性腫癐が本症 の特徴的症状と報告している. しかしこれらの症状を 有しながらも術前䛦断として内へルニアと診断された ものは13 14\%で，大多数の症例の術前㟝断は腸閉 塞・急性虫垂炎・腸重積など多岐にわたり診断の難し さが同われる ${ }^{8) 10)}$. 診断に関しては臨床症状に加えて， 上部消化管造影検査や腹部 CT 検査が行われる. 特に 腹部 CT 検査の普及により, 本疾患の術前診断は向上 してきた.しかし、ルーチン検査として施行しうる腹 部単純写真が診断に有益であったとの報告もある゙”。 一般的に上部消化管造影検查では亳状の小腸陰影像, 赛内小腸での造影剂の通過遅延および輸出入脚も同時 に認めることを特徵とされ，腹部 CT 検査では一塊を

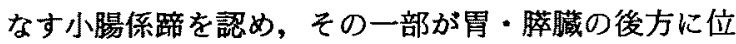
置し，腸腰筋に接していることなどが特徴とされてい

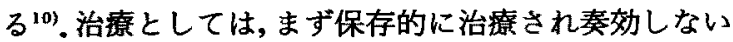
場合には手術が行われることが一般的である5．手術 方法注一般的にヘルニア内容の整復とヘルニア門の閉 鎖である ${ }^{8}$.しかし，経過中に腸管壊死や穿孔といった 合併症を証めた場合には腸切除も必要となってく $3^{1) 723}$. 本症例では腹部腫瘤の触知や明らかなイレウ ス症状は認めなかったが, 約半年間の腹痛持続に加え て前医で腹部エコー検查や上部消化管内視鏡検查で 異常が認められなかったため，消化管精查の目的で上 部消化管造影検查を施行した。これにより小腸の走行 異常を疑い，腹部 CT 検查を施行し術前に揨断を得る ことができた。結果的に手術に際しては小腸嵌頓の可 能性があったが，ヘルニア門閉鎖のみで終えることが できた．しかし，臨床症状のみでは決して診断するこ とはできず，画像診断が非常に有用であった，原因不 明の間欠的腹痛や手術既往のない小腸閉塞 - 絞扼に遭 遇した際は本疾患を念頭に置く必要があるとの報告も ある ${ }^{13) 14}$. 急性腹症を呈す疾患は多吱にわたる。そのな かで本疾患は非常に稀な疾患である。それ故に本疾患 が念頭になければ，衍前に診断することは非常に困難 であると思われる，また最近の外科領域では低侵襲手 術が話題となっているが，本疾患においても腹腔鏡下 に手術を施行された報告もある ${ }^{15)}$. 今後は早期診断と 低侵襲手術により本疾患の概念も変化していくと思わ
れる.

\section{結語}

非常に稀な傍十二指腸ヘルニアの 1 例を経験した。 本疾患は上部消化管造影検査や腹部 $\mathrm{CT}$ 検査により術 前猃断が可能であり，緊急手術や腸管切除を回避する ことがでる．そのためには，本疾患の存在を念頭に おいて診察することが必要である。

\section{文献}

1）遠近值成，公文正光，荒木京二郎：左傍十二指腸 ヘルニアの 1 例. 日臨外医会誌 $57: 389-392$, 1996

2) Schaffler GJ, Groell R, Kammerhuber F, et al : $A$ anterior and upward displacement of the inferior mesenteric vein : a new diagnostic clue to left paraduodenal hernia? Abdom Imaging $24: 29-31,1999$

3）平松望史，千木良晴ひこ，加藤岳人他：腸閉塞に て哭症した高齢者腸回転異常症（右傍十二指腸へ ルニア）の1例. 日消病会誌 $96: 29-32,1999$

4）高畑太郎，長谷川善枝，佐藤浩一他：当科で経験 した左傍十二指腸へルニアの一例. 弘前病医誌 $9: 66-69,2000$

5）飯塚昌志，今村幹雄，國井康男：傍十二指腸へル ニアの 1 手術例. 日腹部救急医会誌 18 :295一 298, 1998

6）藤井 正, 戸谷拓二，渡辺泰宏他：傍十二指腸へ ルニアーその左右診断に関する考察一，日小児外 会誌 $22 ： 1078-1081 ， 1986$

7）坂東儀昭, 吉田金広,三好康敬他：CTにて術前診 断しえた左傍十二指腸へルニアの1例. 日臨外会 誌 $62: 1453-1456,2001$

8）足立 淳, 年光宏明, 下田宏二他：CT にて術前に 診断しえた左傍十二指腸へルニアの1例一本邦報 告例の検討一. 山口医 $47: 197-202,1998$

9）原 義和, 佐藤 泰, 白石良伸他：傍十二指腸人 ルニアの 2 例. IRYO $47: 348-352,1993$

10）菊野隆明，䆶地 淳，奥田 誠他：術後 14 年目に 再発がみられた縦隔型気管支性素胞の 1 例。日胸 外会誌 $43: 350-354,1995$

11) Patil $R$, Smith $C$, Brown $M D$ : Paraduodenal Hernia Presenting as Unexplained Recurrent Abdominal Pain. AJG $94: 3614-3615,1999$

12) Khan MA, Lo AY, Maele DV : Paraduodenal Hernia. Am Surg 64 : 1218-1222, 1998 
13) Hirasaki $S$, Koide $N$, Shima $Y$, et al : Unusual variant of left paraduodenal hernia herniated into the mesocolic fossa leading to jejunal strangulation. J Gastroenterol 33:734-738, 1998

14) Pershad J, Simmons GT, Chung D, et al : Two acute pediatric abdominal catastrophes from strangulated left paraduodenal hernias. Pediatr Emerg Care 14 : 347-349, 1998

15) Uematsu $T$, Kitamura $H$, Iwase $M$, et al: Laparoscopic repair of a paraduodenal hernia. Surg Endsc 12 : 50-52, 1998

\title{
A CASE OF LEFT PARADUODENAL HERNIA DIAGNOSED PREOPERATIVELY
}

\author{
Koji DAIRAKU, Masahiko KISHIKAWA, Tadahiko ENOKI*, \\ Shinji NOSHIMA* and Kimikazu HAMANO* \\ Department of Surgery, Shiroishi Public Hospital \\ -First Department of Surgery, Yamaguchi University School of Medicine
}

We report a case of left paraduodenal hernia diagnosed preoperatively. A 27-year-old man with a 1-year history of upper abdominal pain consulted a medical clinic, where abdominal echo and gastrointes. tinal fiberscopy did not show any specific findings, and thereafter he continued to tolerate the pain without seeking further advice. He was finally seen at the hospital because of the persistent upper abdominal pain. On physical examination, the patient was obviously experiencing upper abdominal pain, but there was no muscle defence. Upper GI series and abdominal computed tomographic (CT) scans showed the small intestine in the stomach dorsum, in front of the pancreas and a diagnosis of left paraduodenal hernia was made. A laparotomy was performed and the hernia orifice was closed. Paraduodenal hernia is a well known cause of acute abdomen, and it is certain to be diagnosed intraoperatively. However, upper GI examinations and abdominal CT scans are very useful for making the early preoperative diagnosis of this disorder, whereby emergency surgery can be avoided. 